\title{
EDITORIAL
}

\section{A PERSONAL RETROSPECT AND PROSPECT}

For those of us involved in the establishment of the Society, it hardly seems possible that only six-and-a-half years have passed since that inaugural conference at Corpus Christi College of some eighty interested parties. That membership now stands near the five-hundred mark is a tribute not only to those who had the initial vision - notable among them the now departed Garth Moore and Graham Routledge - but also to the officers and committee members who have worked hard and incessantly to bring about this happy state of affairs.

With annual conferences alternating between a provincial residential and a London day event, with a growingly prestigious journal making a significant contribution to academic and practical concerns and, above all, with the stimulation of an increasing awareness of ecclesiastical and canon law in the Church at large, there is much for which to be thankful. Nor are these generalities all. To revert to the Journal, now happily found among the periodicals of a number of academic institutions and libraries (though members could do much to swell the number); the learned articles on canonists, the regular features of current legislation and otherwise unreported cases, together with a range of specialist articles from sanctuary to blasphemy; these are the hall-marks of a valuable, and unique legal organ.

Again, the cross-disciplinary representation of the membership is reflective of all those whose professional concern is with the making, administering and interpreting of the Church's law. While there is an imbalance of categories bishops, deans and academic lawyers being grossly under-represented, and a disparity of diocesan membership, as well as a bewildering absence of some chancellors (Why?), the mix of interests ecclesiastical and legal makes for informative discussion at conferences and a growth in mutual understanding. No longer do we hear, as at an early conference (truly), from a lawyer - 'What exactly does an archdeacon do?' and, from a parish priest - 'I thought Lord MacKay was the chancellor'.

Perhaps one of the outstanding success stories of the Society has been the formation and output of its Working Parties. Ranging over marriage discipline, the training of archdeacons and a survey of peculiars, among other topics, they have been able both to respond to the felt needs of the day and also to engage in ongoing examinations of perennial concern to the Church and its law. It should be remembered that the thriving University of Wales degree course in ecclesiastical and canon law, well set to produce the next generation of canonists, was born of the Working Party on training, which indentified a need and had it taken up by two of our members in the Cardiff Law School.

So far, so good, but there is no room for complacency. Mention has already been made of the imbalance in membership. Bishops, deans/provosts, archdeacons, chancellors, registrars, diocesan secretaries, legal academics, should be looking round their circle to identify and encourage their colleagues to join a Society which will both enrich their service and itself be enriched by their membership. There is potential still for doubling our membership and with it, our influence for good on legal thought and practice within the Church. It should not 
be forgotten that a small, but valued, section of the membership is made up of parish priests with special interest and competence in the field. They keep our feet on the pastoral ground.

Two potential growth areas, already represented, are an overseas membership and an ecumenical dimension. With uncertainty about possible withdrawals from the Church of England over recent legislation, the Society may have to consider its attitude to applications for membership from those in 'continuing churches' or a 'third province'. We already gain much from a distinguished Roman Catholic member of our editorial board.

A thought for some of our members - what about joining those other bodies whose interests march alongside our own? Less than half-a-dozen ELS members belong to the Selden Society, while only two are known to be members of the Canon Law Society of Great Britain and Ireland. There is scope for injecting ecclesiastical matter into the one, and Anglican issues into the other.

To end with, three personal hopes. May we have, in parallel to the excellent canonists series already noted, one on leading Deans of the Arches Lushington, Phillimore, et al? May we also sharpen thinking already in train about the publication of occasional monographs? And may we consider 'going public' with a celebrity lecture once in a while, open to non-members? I am grateful to the Editor for allowing me to reminisce and gaze into the future. The Society has widened my horizons considerably. I owe it much, and am glad to have the privilege of serving it.

\section{HUGHIE JONES, Executive Officer}

\section{Four Trees}

68 Main Street

Thorpe Satchville

Meiton Mowbray

Leicestershire LE14 2DQ

\section{WORKING PARTIES}

A number of Working Parties on Establishment, Peculiars, Education in Ecclesiastical Law and Civil Preliminaries to Marriage are currently active. Details appeared in Issue No. 13 of the Journal (July 1993 p. 130) where the names and addresses of Conveners were set out. Please apply to them for information. 